\title{
The Problem of Time from the Perspective of the Social Sciences
}

\author{
JIŘí ŠUBRT* \\ Faculty of Philosophy, Charles University, Prague
}

\begin{abstract}
This article presents a critical review of ideas about time in modern societies and especially in the social sciences. Man in modern society perceives, reflects and registers time in a series of contexts, whether this involves questions of thought, the physical body, nature or society. Current studies that address the question of time in many cases do so through a comparison of archaic temporal awareness and modern temporal awareness, and attempt to describe when and how this historical shift came about. According to O. Rammstedt four distinct historical types of understanding time can be distinguished: (1) occasional awareness of time based on a distinction made between 'now' and 'not-now'; (2) cyclical awareness of time; (3) linear awareness of time with a closed future, and (4) linear awareness of time with an open future. In contemporary social sciences four main theoretical perspectives can be observed. The first one assumes that the basic principles of order are or should be considered as unchanging. These principles express themselves as invariants. In the 20th century we can find it in structural linguistics, and in social sciences with a structuralist orientation. The second approach resembles the previous one in that it also considers the existence of unchanging principles of order. However, it differs through the assumption that these principles reveal themselves in time. The third approach can be considered de facto a sort of special degree of the second, i.e. closed historical concept. Unlike the teleological characterof the latter, however, it considers human intervention as a necessary condition for the achievement of a future aim. The fourth concept is founded on the idea that the basic principles of order can be revealed only in time. Unlike the second, however, it does not consider the main organising principles to be unchanging, but rather concludes that in each contemporary period they are open to change. This fourth approach, which can be described as 'temporalised sociology' and which is expressed in works of such authors as G. H. Mead, A. Schütz, N. Elias, N. Luhmann or A. Giddens is stressing a relatively open future, emergence, novelty and the concept of discontinuity. In the opinion of the author of this study another concept should be added to our understanding of time: i.e. 'irreversibility'. It is a feature of those systems that are far form being balanced and in which, in order to be able to predict future states, it is not enough to know the laws and the initial conditions.
\end{abstract}

Czech Sociological Review, 2001, Vol. 9 (No. 2: 211-224)

In Reason and Culture, Ernest Gellner writes that, thanks to a certain mechanism of evolution, one that has yet to be fully grasped, one remarkable feature of the human race is the striking variability of its reactions. The lack of any preliminary genetic programming of human reactions must in Gellner's view (who on this point makes reference to Durkheim) be compensated with certain social and conceptual limitations. The ability to react to socio-semantic limitations fortunately emerged in our behaviour alongside its pliability

*) Direct all correspondence to: PhDr. Jiří Šubrt, Department of Sociology, Faculty of Philosophy of the Charles University, Celetná 20, 11000 Praha 1, e-mail jiri.subrt@ff.cuni.cz 
[Gellner 1992]. Human notions of time are, as will be demonstrated here, a part of these socio-semantic regulators.

As Helga Nowotny notes, time in the life of society has 'many faces' and assumes various shapes and forms of expression. It permeates every aspect of social life and is a basic component of all social phenomena [Nowotny 1992: 499]. In the words of Barbara Adam, time is predetermination and a necessity for all human societies, regardless of whether the language of that society has a special designation for it or not. It is an essential precondition of any thoughts on human society or social order, and on stability or change within them.

Man in modern society perceives, reflects and registers time in a series of contexts, whether this involves questions of thought, the physical body, nature or society. In addition, it represents the standard method of measurement, co-ordination, regulation, and control, which is today applied world-wide. In these diverse forms time is understood as a part of life in society that is inherent, and simply taken for granted. Paradoxically, despite the fact that we are surrounded by it, it continues to elude us. It is so deeply rooted in our existence that it is almost 'invisible' [Adam 1990: 9]. This fact leads to the problems associated with efforts to understand and investigate time.

\section{The construction of ideas about time}

Edmund Leach connects the heterogeneity of ideas about time with two basic experiences: (1) certain natural phenomena are recurrent; (2) for the human organism, changes in life are irreversible and death unavoidable [Leach 1961: 125]. The construction of ideas about time, in the form of certain typologies that become a part of our available stock of knowledge, is founded on certain, anthropological types of assumptions. Key among these is the elementary fact that man is a creature imbued with reason who is born and dies. The duration of human life is thus clearly oriented along 'time's arrow', which moves unwaveringly from a beginning to an end. However, of no less importance is the fact that in the world of life we live in, we are surrounded and influenced by a series of phenomena that are characterised by rhythmic alternations or repetition (e.g. the rhythmic alternation of the four annual seasons), which in turn enables us to measure particular and individual lengths of time (e.g. we can measure the length of our lives through the number of springs we have lived through).

The specific human relationship to what has been and what will be is important for the construction of ideas about time. In this connection the idea of John Ellis McTaggart is worth remembering, as he referred to two concepts of time: the objective concept, which distinguishes between early and late stages - these types of relationships are designated as B-time series - and the subjective concept, which incorporates the observer and the observer's past, present and future within the analysis - the A-time series. Series B is considered sufficient for a description and explanation of nature. In order to investigate the human world, however, it is necessary to use both types, as human awareness of time contains both the experience of real successions, and the ability to remember, reflect and expect. Series B (before/after) creates a time structure that refers to relationships and events that are identical for all observers. Conversely, in series A (past, present, future) the definitions of today, tomorrow and yesterday change in connection with the observer and the observer's awareness. Barbara Adam states that all societies make distinctions between events according to time series $\mathrm{A}$ and $\mathrm{B}$, including those societies whose lan- 
guages do not make corresponding distinctions in tenses or have no separate term for what we call time [Adam 1990: 21].

Norbert Elias [1992] views time as a tool for orientation, which is created on the basis of inter-comparisons between multiple, continuous actions. What we refer to as time is in his opinion a kind of relative framework, which aids people in creating orientation points within the continual flow of changes. This framework enables the inter-comparison of the individual phases of actions, and various, recurring or particular events serve people as socially standardised orientation points: the seasons, tides, movements of the sun and moon, the birth of Christ or the prophet Mohammed.

According to Elias, time is determined through the ability to inter-connect two or more different sequences of continuous changes, one of which serves as a measure for the other or others. The concept of time is founded on what is common to the sequences, regardless of their differences in terms of substance. The word time is a symbol for a relationship that groups of humans (thus groups of creatures with the biologically determined capacity for remembering and synthesis) set between two or more courses of events, of which one is taken as a relative framework or measure for the standardisation of the others [ibid.: 12]. For certain events to be asserted as 'time' requires a connection between a minimum of three continua: between people and between two or more continua of changes, of which one is chosen by a certain group of humans as the standard continuum, as the relative framework in relation to which the rest is measured (first man made use of the continual sequence of what we call natural events, and then to a growing degree made use of mechanical sequences formed by humans).

Many authors (e.g. E. Durkheim and P. A. Sorokin) set the question of temporal ideas in connection with the development of abstract thought. Unlike these authors, Elias considers it more apt to speak not of abstraction (it is difficult to say which specific phenomena time was abstracted from) but of synthesis. Time-like the concepts of nature, cause or substance - is a result of 'synthesis on a high level', which was reached in the process of development from particular to generalising syntheses.

Memory is of key importance in these thought acts. Concepts such as 'earlier' and 'later' are manifestations of the human ability to group together in their ideas that which did not actually occur together, and which was therefore not even experienced by people as occurring together. Memory plays a decisive role among all forms of determining time as an essential precondition for the human ability to create a synthesis (e.g. it would make no sense to say that it is now four o'clock if at the same time it were not possible to be aware of the fact that earlier it was two o'clock and later it will be six o'clock).

One complication in the attempt to grasp the entire problem stems from the fact that, from the very beginning, humans have referred to recurring natural phenomena as a measure of this tool of orientation. As a result, they tend to project specifically human socially construed - ideas of time into non-human reality, to use this - by nature social tool as the measure and explanatory principle for natural and cosmic events.

Like many other social products, the way in which time is determined evolved throughout the centuries to its current state in connection with the rise of certain social requirements. The first of these is the need to co-ordinate and synchronise the course of human activities in relation to each other and in relation to non-human nature. This kind of requirement does not arise in all societies with the same intensity; the larger, more populated, more differentiated and complex a society is, the stronger the requirement is, 
too. It grows with the increase in urbanisation and commercialisation, which lead to the need to make use of a balanced, forward-running temporal raster as a general relative framework for synchronising the growing number of human activities. This task (on which, among other things, matters such as regular tax payments, interest, and the fulfilment of contracts and obligations depend) is taken up by central - church or secular institutions that find support in physical models; this development is supported by the technical innovations of first tower clocks, and later pocket and wrist watches. This temporal awareness, that penetrates everything, becomes an integral part of the social 'canon' of relatively complex, urbanised societies and the personalised structures of their members. Time is endowed with a compelling force that stems from its social functions.

Elias considers the forms of experiencing time as aspects of social habit. Through numerous examples he demonstrates that people have not always experienced the mutual relationships of events in the manner that is typical for modern man. The human experience of what is today called time, transformed itself in the past and continues to change in the present. Contemporary man may of course assume that the models of self-regulation experienced now are normal, universal, human features, and need not be aware that this approach is the product of a long-term process.

Current studies that address this question in many cases do so through a comparison of archaic temporal awareness and modern temporal awareness, and attempt to describe when and how the change came about in which many varied 'local times' evolved into a single universal time, and the original multiplicity of the highly varied, locally differentiated ideas and systems of measuring time was replaced with the single, balanced, and meticulously segmented temporal raster of hours, minutes and seconds shared by all. In this connection E. T. Hall [1983] speaks of the 'polychronic' time of archaic societies and the 'monochronic' time of modern society, and M. Young refers to the transformation of the natural rhythm into a 'metronomic pulse'.

One of the attempts to describe the development in this area is the concept of the German author O. Rammstedt, who was led by the differences in the historical types of understanding time to distinguish four distinct forms [Rammstedt 1975: 47 et seq.]:

1. occasional awareness of time (founded on a distinction made between 'now' and 'notnow');

2. cyclical awareness of time (including the distinction of 'before' and 'after');

3. linear awareness of time (past/present/future) with a closed future;

4. linear awareness of time with an open future.

What is characteristic of the first of these forms is that time is viewed as an oscillation between opposites: night and day, winter and summer, drought and flood, youth and old age, life and death. The past has no depth; no matter how near or distant it remains only the opposite of the present. Edmund Leach [1961] refers to this 'flattened' time, which is ascribed by some cultural anthropologists to pre-literate societies, as 'alternating' time, as its flow is similar to the flow of an alternating current in an electrical circuit. This author is trying to underline the non-cyclical essence of alternating time with the claim that the geometric notion of time in the form of a circle is a thought foreign to 'unsophisticated' societies.

Leach's idea of archaic, alternating and non-cyclical time was criticised by Robert Barnes [1974], who claims that the typical form of the collective representation of time in 
pre-technical societies is not one of zig-zaggy alternations, but is rather cyclicity, or periodicity. The defining feature of primitive temporality is in Barnes' view a noncumulative repetitiveness rather than a pendular alternation. If we were to accept Barnes' argument, in the above-mentioned concepts of four historical forms of understanding time, we could dispute the idea of occasional awareness of time as the first phase, and view the second form, cyclical awareness of time, as the starting point.

In societies in which the awareness and conduct of people is to a substantial degree determined by the flow or cycle of alternating annual seasons and agriculture labour, tradition plays the dominant role. The life of the people is founded on the reproduction of models of behaviour, the content of which was established in the past by the society's ancestors. For this reason it is often said of individuals in archaic societies that they did not see the future, but rather shrunk towards it with their backs turned and their faces looking towards the past.

Cyclicity, however, also expresses itself on the level of historical consciousness. In the book The Myth of the Eternal Return, Mircea Eliade [1993] attempted to reconstruct the manner of people's thought that was connected with the idea of some sort of eternal cycle occurring place in the form of recurring circular returns. Eliade demonstrates that our idea of a linear passage of historical time in the direction from the past to the present and into the future was not characteristic of people in archaic societies. Their perspective saw a history filled with eternal repetitions. In Eliade's view, what societies of the traditional agrarian type and the large old civilisations of Europe, Asia and America had in common was that while they did indeed have knowledge of a certain form of history they tried not to reflect on it; among these societies, the resistance to concrete historical time was linked with a desire for periodic returns to a mythical age at the beginning of time.

In this connection Claude Lévi-Strauss, in La pensée sauvage [1971], speaks of a 'never-ending battle' between synchronism and diachronism, which he illustrates in the example of the function of sacred objects that Australian aborigines call 'churingy': the task of these objects is to destroy time, to annul the results of its passage, to enable contemporaries to communicate with predecessors, and to enable them to connect with their predecessors in a synchronic manner.

These and other similar interpretations, as Alfred Gell [1992] has recently shown, contain certain pitfalls. The problem may be summarised in a simplified way through the following questions: Did the members of these societies really believe that time repeats itself cyclically, or were they aware of its irreversibility and tried by means of religious myths, rituals and practices to struggle against it in every possible way? Eliade's formulation of the attempt not to reflect on history and the desire for periodic returns, and LéviStrauss' idea of the ritual which is the 'tool for destroying time' testify rather to the second idea.

One way or the other, the onset of Christianity had a significant influence on the reconstruction of ideas about time. Here we arrive at another historical form of understanding time, which is a linear awareness of time with a 'closed' future. Unlike antiquity, which is attributed with maintaining a cyclical concept of historical time, the middle ages are characterised by a finalistic conception of movement from creation to the end of the world. The re-construction of the structure of temporal ideas in medieval Europe is connected with the transition from paganism to Christianity, in which the interpretation of time was based on three key moments representing the beginning (creation), culmination 
(the coming of Christ and death on the cross), and the end (the last judgement). Owing to these 'strategic points', historical time is straightened, and becomes vectorial, linear and irreversible [Gurevič 1978: 87]. Historians dealing with these periods usually point out that through the influence of Christianity the archaic relationship to time was not so much uprooted as it was shifted into the background, and thus during the middle ages two concepts existed alongside one another: the cyclical time of recurring natural phenomena and agricultural labour, and linear time, bound up in Christian religious tradition.

The idea of a 'closed' future is also connected with the Judeo-Christian religious tradition, as it is connected with eschatological visions of the end of the world and history. The eschatological viewpoint influenced European thought for a very long time, became the source of inspiration for the philosophy of history and significantly stimulated reflections on the meaning of history. From the time of the Renaissance, however, secularising tendencies began to express themselves in eschatological thought. These came to a peak during the Enlightenment, which substituted the prospect of salvation with the idea of progress (the logical outcome of this secularising tendency was Marxism, in which the end of history assumed the form of a classless society).

The eschatological orientation towards the future is connected with the idea of a certain finale or end. Set against this is the final (fourth) form of understanding time, with the emphasis on an 'open' future. The idea of an open future is connected with the expansion of science and technology, which began its remarkable acceleration in the 19th century. As a result of this expansion, the horizons of the future and the past were transformed in a significant way. If for religious thought the past and the future were framed with a beginning and an end, at this point vast 'chasms' in either direction now opened up in front of people. Let us recall the kind of problems that were introduced at this time, for example, by the confrontation between opinions founded on biblical tradition and opinions founded on new discoveries in the fields of geology, palaeontology and archaeology. In the intellectual atmosphere in which Darwin's theory of evolution was born, the idea of an open future emerged, one with no pre-set scenario or pre-set outcome.

\section{From the sociology of time to temporalised sociology}

Although sociological research of time has a relatively long and interesting history, until the end of the 1970s interest in this phenomenon was rather marginal. Émile Durkheim and his colleagues played a pioneering role in this research. According to Durkheim, time expresses the rhythm of collective life. It is a category of our thought, which has a social origin in the sense that has been abstracted from the collective life of the people [Durkheim 1981: 588]. If in our thoughts we are dealing with time as a subject, this means that we have borrowed a model from society that we now project into all the other spheres and areas that surround us.

Durkheim's ideas had an influence on the fields of sociology (M. Halbwachs, G. Gurvitch), cultural anthropology (C. Lévi-Strauss), and historical science (the Annales school). They were unquestionably influential for P. A. Sorokin and R. K. Merton [1937], who considered social time to be one of the possible concepts of time alongside economic, psychological, and astronomical time, etc. In the view of these authors, social time - unlike time as it is considered in physics - has a qualitative character, it does not pass in a uniform manner, and it cannot be randomly divided. That through further historical development a quantitative concept of time came to assert itself against this qualitative concept in the awareness of modern man is a result of the processes of modernisation. 
Georg Simmel (like many authors after him) drew attention to this fact, linking the establishment of clock time with the assertion of modern rationality, which tends to "convert the world into an arithmetical problem and determine each of its parts with the help of mathematical formulas'. According to Simmel, this approach corresponds to the mathematical precision of practical life, which emerged with the introduction of a money economy. Given the arithmetic character of money, precision established itself in behaviour, agreements, and arrangements, which was expressed through the general spread of the pocket watch. The materialised form of these tendencies is represented in Simmel's view by the big city. The relationships and affairs of the big city are multifaceted and complicated. As many people with different interests came together, the relationships and governance of this kind of rugged organism became impossible without genuine exactness, as otherwise everything would collapse in indecipherable chaos.

Simmel's thoughts bring us to the issue of temporal order, the organisation of time, its distribution in social systems and controls. One of the first ambitious attempts at grasping the complex time structures of society was the work of Georges Gurvitch, $L a$ multiplicité des temps sociaux [1964], in which he speaks of the pluralism, or the multiplicity of versions of social time. In Gurvitch's view, the life of society in its various forms flows according to extremely varied and often divergent kinds of times, which often compete and are set mutually in conflicting relationships, and their unification (necessary, but relative) demands a maximum of effort and poses a problem for all of society. Each society, social class, individual group, or micro-social phenomenon (related to myth, religion, magic, economy, technology, law, politics, knowledge, morals or education) tends to occur in its own version of time.

No society, social class or structured group (regional, professional, family, etc.) can exist without attempting to control these numerous kinds of social time (which does not mean that they always succeed in doing so). Each social unit, class, group, micro-social element, relationship, or activity tends to occur in a kind of time that is particular to it alone, and conversely every society attempts to unify this plurality of times. The effort to install a relationship of cohesion and co-ordination among the different kinds of social time leads to the creation of a specific gradation of these times in which the individual social structures are gravitate and attempt to dominate. According to Gurvitch, everything is located in the constant motion of structurising, destructurising, and restructurising where they collide with one another and sometimes even 'explode'.

Interest in the phenomenon of time grew remarkably in the 1980s. A subject that until then had been often overlooked became almost fashionable. Numerous papers [Bergmann 1983, Elchardus 1988, Nowotny 1992], monographs [Schops 1980, Lauer 1981, Bergmann 1981, Hall 1983, Hohn 1984, Rifkin 1987, Elias 1992, Young 1988, Nowotny 1989, Dux 1989, Kellerman 1989, Pronovost 1989, Adam 1990, Ferrarotti 1990, Gell 1992, Baert 1992, Nassehi 1993, Sue 1994, Adam 1995, Schlote 1996], and essay collections [Das Phänomen... 1984, Zeit als... 1986, Zeit-Zeitlichkeit... 1986, Die sterbende... 1987, The Rhythms... 1988, Zerstorung... 1988, Die Zeit... 1989, Im Netz... 1989, The Sociology... 1990, Ökologie... 1993, Zeit - Medien... 1994] appeared, and many professional seminars and symposia were held, some of which had an interdisciplinary approach. That research in this field underwent such a rapid development can be demonstrated indirectly through the fact that the sociology of time (Zeitsoziologie) is today viewed as a type of independent discipline in the field of sociology. 
There have been numerous attempts to address the problem of time in the framework of contemporary sociological theory, but the picture they form is more of a mosaic, whose individual parts are difficult to integrate. A large number of existing studies today offer a broad palette of often irreconcilable opinions, so the reader can easily get caught up in a labyrinth where there are few clear signs of direction. The theories are built around a common intention, but whoever might seek any lesson amidst this mass of ideas soon runs into a considerable problem: how to orient oneself amidst this variability, how to gain an orientation with the aid of this heterogeneous stock of thoughts, how to integrate isolated concepts and make a coherent and meaningful unit out of them [Adam 1990: 15].

Agreement reigns over the point that time has yet to be studied in a thorough and adequate manner, and it has yet to be adequately dealt with within the framework of social theory. Efforts to overcome this state of affairs have thus far been oriented towards solving three inter-related problems: (1) the constitution of time as a social category; (2) the functioning of temporal structures on various levels of social systems; (3) the place and role of time in general sociological theory.

Once questions concerning the relationship of time to sociological theory have been established, the entire discussion shifts to the meta-theoretical level. There it essentially deals with the problem of what the general sociological theory that time plays a decisive role in ought to look like. One author who at the beginning of the 1990s formulated a demand for a thorough examination of this issue is Patrick Baert [1992], who coined the term 'temporalised sociology'. This term refers to a direction in research that is somewhat distinct, though in no way runs counter to what the sociology of time actually is at present - it has become a sort of all-embracing term for a varied spectrum of theoretical and empirical types of research that today continues to expand in all directions, i.e. towards an ever greater variability in content and subject. Baert's primary interest is in the concept of time on the conceptual level, in planting it firmly within the framework of contemporary theoretical and meta-theoretical discussions, where process and diachrony should be fixed as the ontological foundation and methodological starting point of the analysis of social systems.

The essence of the problem we come to now can be conveyed through the distinction between four theoretical viewpoints. The first assumes that the basic principles of order are or should be considered as unchanging. These principles express themselves in time and space as invariants. Baert refers to this type as the concept of 'the eternal permutation of time' [ibid.: 5], because all changes that can be observed in time represent according to this concept a mere and imperfect 'permutation' or 'combination' of unchanging eternal principles. The roots of this approach go back to the Greek atemporal tradition established by Parmenides and Plato, in which a distinction is made between the world of permanent, eternal principles, which can be grasped by reason, and the world of transient phenomena, which we perceive through our senses. The Greek idea of an unchanging atemporal world had an influence on European thought for a very long time. In the 20th century we can find it in structural linguistics, and in social sciences with a structuralist orientation. The basic idea of structuralism in the social sciences is founded on the assumption of an unconscious, atemporal logic, which is to be revealed as common to all cultures in the present, past and future. 
The second approach resembles the previous one in that it also considers the existence of unchanging principles of order. However it differs through the assumption that these principles reveal themselves in time. It is a concept that lays emphasis on the passage of time, but it is also true of this concept that the future it will reach is closed. In comparison with the preceding concept of 'eternal permutation', time in this concept gains in meaning, but the meaning is relativised in that the passage of time does not create any new principles and does not count on the appearance of anything new and unexpected. In this case Baert speaks of a 'closed historical concept' [ibid.: 6], where the term 'closed' refers to the postulated unchangingness of the main principles. The forerunners of this concept can be traced in the teleological aspects and in the finalistic principle of the teachings of the Old and New Testaments (which was the antithesis of the primarily atemporal worldview of Greek civilisation). A similar view of the world appears later in the philosophy of history, the pioneers of which include personalities such as Turgot, Condorcet and Herder. The closed historical approach maintained a dominant position in the science and philosophy of the 19th century.

The third approach can be considered de facto as a sort of special degree of the second ('closed historical') concept. Unlike the teleological character of the latter, however, it considers human (usually scientifically founded) intervention as a necessary condition for the achievement of a future aim. This third concept can be traced in the ideas of Saint-Simon, Comte, and even Karl Marx, and later Karl Mannheim, too.

The fourth concept - similar to the second, 'closed historical concept' - is founded on the idea that the basic principles of order can be revealed only in time. Unlike the second concept, however, it does not consider the main organising principles to be unchanging, but rather concludes that in each contemporary period they are open to change. It therefore exhibits a fundamental difference in that it postulates 'an open future'. This concept became an integral part of Western thought only during the 19th century, and Darwin's theory was considerably instrumental in its formation. H. Bergson may be considered as another of its pioneers, with his ideas on cosmic vitalism and time as an invention. From earlier periods in the evolution of sociology, G. H. Mead may be viewed as a representative of this stream, among authors of a later date, A. Schütz and N. Elias represent it, too, and in contemporary sociology it can be traced primarily in Luhmann's sociology, founded on the theory of 'autopoiesis', and Giddens' theory of structuration.

The question of time is present throughout the work of George Herbert Mead. He connects the essence of time with the terms 'emergence', 'event', and 'novelty'. Emphasis is placed on 'the emerging' and 'the new'. In this case, the theory of relativity played an inspirational role, wherein each experience is dependent on the perspective and location of the observer, as did Whitehead's philosophy [Mead 1967: 523 an.], which attempts to grasp reality through the event as a concept. Mead follows up on Whitehead's ideas by showing that the unity of reality is created by events. The limitless number of possible simultaneities between each single event and other events creates numerous temporal orders of this event and countless thought perspectives from which these temporal orders may be viewed. Events are imagined not as a mere part of a single flow of time, but rather as something that construes time. With each new exceptional event a new present is constituted, out of which is arranged both everything that has passed and the future anticipated course of events. 
Alfred Schütz subscribed to the Weberian interpretation of 'understanding' sociology founded on the concept of action, out of which the agent of the action derives a certain sense. One of the perceived weaknesses in Weber's approach is that it is founded on a certain concealed assumption, as it does not ask about the constitution of sense for the agent of the action. It is this problem that Schütz focuses on, applying in his reflections impulses arising out of the philosophical work of E. Husserl and H. Bergson. Sense in Schütz's view is constituted through the formation of relationships between data of consciousness. This leads him to an opinion that may be concisely expressed as: Sinnproblem ist ein Zeitproblem - the problem of sense is a problem of time [Schütz 1960: 8]. He believes that with the aid of a general theory of consciousness, such as Bergson's philosophy of duration or Husserl's transcendental phenomenology, it is possible to solve the riddle that the phenomena of the establishment of sense and its interpretation presents us with [ibid: 10]. He claims that with the help of a phenomenology of an internal consciousness of time it is possible to examine the problem of subjectively inferred sense. On this basis he then deals with the question of understanding the action of others and the meaningful construction of the social world. Given that for Schütz the question of sense, and thereby also the entire constitution of social reality, is a question of time, it is possible without exaggeration to say that it is with Schütz that the tendency towards a radical temporalisation of the theory of the constitution of the social order begins, a tendency that is continued by major representatives of contemporary sociology such as N. Luhmann and A. Giddens.

Another notable example of temporalised sociology is the civilisation theory of Norbert Elias. One characteristic feature of Elias' sociological thought is its orientation around process, an orientation towards researching the trends in the development of social and personality structures. Elias' interest is attracted by processes of continual, long-term changes. These are processes that occur, but not deliberately or according to plan, and which also have no absolute beginning (zero point) from which to unfurl, and no end to inevitably head towards.

Within the framework of system theory, Niklas Luhmann [1988] examines the problem of time from various viewpoints. He examines questions of the constitution and social production of time, world time (Weltzeit), temporal order, counting time, and chronology. His interest lies in the problem of temporal linearity and cyclicity, temporal horizons of the past and future, social changes, the temporal structures of the individual partial social systems, and so-called temporal anxiety (Zeitknappheit). Sociology under the influence of Luhmann deals with time on three levels of social systems - interaction, organisation, and society [Bergmann 1981].

Anthony Giddens considers the fundamental problem of sociology to be the problem of order, which he conceives as a problem concerning the arrangement of society in time and space [Giddens 1988: 161]. According to Giddens' theory of structuralisation, each moment of social reproduction encompasses three intersecting, and interpenetrating levels of time: (1) the temporality of direct experience, that is, the continual passage of everyday life - that which Schütz, along the lines of Bergson, refers to as duration $(d u$ rée); (2) the temporality of being (Heidegger's Dasein), that is, life and its cycles; (3) long durée (Fernand Braudel's term) - the 'long term' of institutional time, connected with the development and reproduction of social institutions [ibid: 89]. 
A significant feature of modernity in Giddens' view is that with it there occurs a 'transformation' of time and space [Giddens 1998: 23]. If in pre-modern cultures time was always calculated in connection with a specific place ('when' was tied to 'where'), modernity leads in the first place to the 'emptying' of time and space (into the form of abstract co-ordinates), and in the second place to their separation (which at the same time, however, becomes the precondition for their new rearrangement). This separation is significant primarily because (a) it abolishes its traditionally fixed nature (i.e. it frees it from the bonds of local limitations), (b) it makes it possible to combine the local and the global in a manner unthinkable within traditional societies, and (c) it creates conditions in which time and space can again be combined to form a unified, worldwide framework. Expressions of these tendencies can be registered even in the early stages of modern society, but the present stage, which Giddens refers to as 'radicalised modernity', leads to a situation in which they become significantly deeper.

\section{A concluding note on irreversibility}

The first and most important term used in temporalised sociology is in the view of Patrick Baert 'a relatively open future', and the idea of discontinuity that is connected with this. Other important terms include 'emergence', 'novelty' (used by G. H. Mead), and Bergson's term durée - duration. This list should in our view be expanded to also include the term 'irreversibility'.

In the work, Where are the Social Sciences Heading, by Immanuel Wallerstein et al., the problem of irreversibility receives a great deal of emphasis, although it is illustrated through the example of the natural sciences. According to the authors of this study, Newtonian physics describe stable and temporally reversible systems, which of course represent only a specific and limited part of reality. For example, Newtonian physics describe the movement of the planets, but not the evolution of the planetary system. They describe a system in balance, or a system near to balance, but not systems that are far from being balanced, and thus circumstances that are equally as frequent if not more frequent than balanced systems. The circumstances of the system that is far from being balanced are not temporally reversible conditions in which in order to be able to predict future states it is enough to know the laws and the initial conditions. The system that is far from being balanced is rather an expression of where time is headed, the role of which is fundamental and constructive. In this kind of system the future is uncertain and the conditions are irreversible. The laws that we can form thus only enumerate the possibilities and not the certainties.

As a consequence, irreversibility is no longer considered a flawed scientific discovery, the outcome of an approximation resulting from insufficient scientific knowledge. Scientists today are working on an expansion of the laws of dynamics so as to include irreversibility and probability. It is assumed that only in this way can scientists hope to gain an understanding of the mechanisms that - on the basic level of description - propel the restless universe we are rooted in [Wallerstein 1998].

Since the time of Emile Durkheim the attention of sociologists has been turned towards the problem of social time, primarily on the level of its symbolic representation the level of 'symbolic' time. This established a certain split, separating this time from natural (cosmic) time. Focusing attention on 'symbolic' time has proved to be a productive and important step for other sociological research, but at the same time this step established a dualism, separating society from nature (or, non-reflexive systems). Even 
today we can come across social theory that is only very slightly oriented towards dealing with time in any expression other than a 'symbolic' one. But there are problems that cannot be solved within the framework of the social sciences alone. One such problem is the above-mentioned issue of irreversibility. S. W. Hawking, the well-known astrophysicist, in this connection refers to three arrows of time: thermodynamic, along the direction of which disorder increases; psychological, whose direction is given by the fact that we remember the past and not the future; and cosmological, which is defined according to the expanding direction of the universe. Hawking asks why all three are moving in one direction, and how is it that any meaningful arrow of time can exist at all? In his attempt at an answer Hawking connects the direction of time's arrows with the direction in which the universe is expanding [Hawking 1991: 141 et seq.].

Even though for the time being there is no consensus over the question of whether the theory of time is an essential condition for the construction of a general sociological theory, it is possible to state that the problem of time is a transversal sociological problem that is present in every sociological theory and every piece of research, even if at times in the form of a concealed assumption. This also explains why at present the opinion is spreading that a better understanding of time can contribute not only to revealing partial deficiencies and problems in the social sciences, but also to the overall development of theory and research. Sociological studies, as radical critics put it, will remain bad until sociologists gain a better understanding of the essence and function of time. With respect to the traditional dualism of social and natural time it is furthermore necessary to draw attention to the growing conviction that this is not only a matter of some specialised branch of the social sciences but rather something that in its very essence is interdisciplinary.

Translated by Robin Cassling

JIŘí ŠUBRT lectures at the Faculty of Philosophy of Charles University in Prague. He works on sociological theory, public opinion research, and media. He is the author of the books The Civilisation Theory of Norbert Elias (Praha, Karolinum), The Problem of Time in Sociological Theory (Praha, ISV 2001), and headed the collective work Chapters from the Sociology of Public Opinion Research (Praha, Karolinum 1998).

\section{References}

Adam, B. 1990. Time and Social Theory. Cambridge: Polity Press.

Adam, B. 1995. Timewatch: The Social Analysis of Time. Cambridge: Polity Press.

Baert, P. 1992. Time, Self and Social Being: Temporality Within a Social Context. Avebury: Aldershot.

Barnes, R. 1974. Kédang. Oxford: Clarendon.

Bergmann, W. 1981. Die Zeitstrukturen sozialer Systeme: Eine systemtheoretische Analyse. Berlin: Duncker und Humblot.

Bergmann, W. 1983. "Das Problem der Zeit in der Soziologie.” Kölner Zeitschrift für Soziologie und Sozialpsychologie: 462-504.

Das Phänomen Zeit. 1984. Hrsg. von M. Horvat. Wien: Literas.

Die sterbende Zeit: 20 Diagnosen. 1987. Hrsg. von D. Kamper und C. Wulf. Darmstadt und Neuwied: Hermann Luchterhand Verlag.

Die Zeit: Dauer und Augenblick. 1989. München: Piper. 
Durkheim, E. 1981. Die elementaren Formem des religiosen Lebens. Frankfurt am Main: Suhrkamp.

Dux, G. 1989. Die Zeit in der Geschichte: Ihre Entwicklungslogik vom Mythos zur Weltzeit. Frankfurt am Main: Suhrkamp.

Elchardus, M. 1988. "The Rediscovery of Chronos: The New Role of Time in Sociological Theory." International Sociology 1: 35-59.

Eliade, M. 1993. Mýtus o věčném návratu [The Myth of the Eternal Return]. Praha: OIKOYMENH.

Elias, N. 1992. Über die Zeit. Frankfurt am Main: Suhrkamp.

Ferrarotti, F. 1990. Time, Memory, and Society. New York: Greenwood Press.

Gell, A. 1992. The Anthropology of Time: Cultural Constructions of Temporal Maps and Images. Oxford and Providence: Berg.

Gellner, E. 1992. Reason and Culture: The Historic Role of Reason and Rationalism. Oxford: Blackwell.

Giddens, A. 1988. Die Konstitution der Gesellschaft: Grundzige einer Theorie der Strukturierung. Frankfurt und New York: Campus.

Giddens, A. 1998. Důsledky modernity [The Consequences of Modernity]. Praha: Sociologické nakladatelství.

Gurevič, A. J. 1978. Kategorie středověké kultury [Categories of Medieval Culture]. Praha: Mladá fronta.

Gurvitch, G. 1964. The Spectrum of Social Time. Dordrecht: D. Riedel Publishing Company.

Hall, E. T. 1983. The Dance of Life: The Other Dimension of Time. New York: Doubleday.

Hawking, S. 1991. Stručná historie času [A Brief History of Time]. Praha: Mladá fronta.

Hohn, H.-W. 1984. Die Zerstörung der Zeit: Wie aus einem gottlichen Gut eine Handelsware wurde. Frankfurt am Main: Fischer Taschenbuch Verlag.

Im Netz der Zeit: Menschliches Zeiterleben interdiziplinar. 1989. Stuttgart: Hirzel.

Kellerman, A. 1989. Time, Space and Society: Geographical Societal Perspectives. Dordrecht, Boston and London: Kluwer Academic Publishers.

Lauer, R. H. 1981. Temporal Man: The Meaning and Uses of Social Time. New York: Praeger.

Leach, E. 1961. Rethinking Anthropology. London: Athlone Press.

Lévi-Strauss, C. 1971. Myšlení přirodních národi̊ [La pensée sauvage]. Praha: Československý spisovatel.

Luhmann, N. 1984. Soziale Systeme: Grundriss einer allgemeiner Theorie. Frankfurt am Main: Suhrkamp.

Luhmann, N. 1988. Soziologische Aufklarung, Bd. 2, 3. Opladen: Westdeutscher Verlag.

Mead, G. H. 1967. Philosophy of the Act. Ed. by C. W. Morris. Chicago and London: University of Chicago Press.

Nassehi, A. 1993. Die Zeit der Gesellschaft: Auf dem Weg zu einer soziologischen Theorie der Zeit. Opladen: Westdeutscher Verlag.

Nowotny, H. 1989. Eigenzeit: Entstehung und Strukturierung eines Zeitgefuhls. Frankfurt am Main: Suhrkamp.

Nowotny, H. 1992. "Time in the Social Sciences. Theoretical and Empirical Approaches." Pp. 481-525 in European Social Science in Transition: Assessment and Outlook, ed. by M. Dierkes and B. Bievert. Frankfurt am Main: Campus Verlag.

Ökologie der Zeit: Vom Finden der rechten Zeitmasse. 1993. Hrsg. von M. Held und K. A. Geissler. Stuttgart: Hirzel. 
Pronovost, G. 1989. “The Sociology of Time.” Current Sociology 37(3).

Rammstedt, O. 1975. “Alltagbewusstsein von Zeit.” Kölner Zeitschrift für Soziologie und Sozialpsychologie 27.

Rifkin, J. 1987. Time Wars: The Primary Conflict in Human History. New York: Henry Holt and Company.

Schlote, A. 1996. Widerspruche sozialer Zeit: Zeitorganisation im Alltag zwischen Herrschaft und Freiheit. Opladen: Leske und Budrich.

Schops, M. 1980. Zeit und Gesellschaft. Stuttgart: Ferdinand Enke Verlag.

Schütz, A. 1960. Der sinnhafte Aufbau der sozialen Welt: Eine Einleitung in die Verstehende Soziologie. Wien: Springer Verlag.

Sorokin, P. A., R. K. Merton 1937. "Social Time: A Methodological and Functional Analysis." The American Journal of Sociology 5: 615-629.

Sue, R. 1994. Temps et ordre social: Sociologie des temps sociaux. Paris: Presses Universitaires de France.

The Rhythms of Society. 1988. Ed. by M. Young and T. Schuller. London and New York: Routledge.

The Sociology of Time. 1990. Ed. by J. Hassard. London: Macmillan.

Wallerstein, I. et al. 1998. Kam směrují sociální vědy: Zpráva Gulbenkianovy komise o restrukturaci sociálních věd [Open the Social Sciences. Report of the Gulbenkian Commission on the Restructuring of the Social Sciences]. Praha: Sociologické nakladatelství.

Young, M. 1988. The Metronomic Society: Natural Rhythms and Human Timetables. Cambridge, MA: Harvard University Press.

Zeit-Medien - Wahrnehmung. 1994. Hrsg. von M. Sandbothe und W. C. Zimmerli. Darmstadt: Wissenschaftliche Buchgesellschaft.

Zeit - Zeitlichkeit - Zeiterleben. 1986. Hrsg. von R. Freig und H. D. Erlinger. Essen: Die Blaue Eule.

Zeit als Strukturelement von Lebenswelt und Gesellschaft. 1986. Hrsg. von F. Fürstenberg und I. Morth. Linz: Trauner Verlag.

Zerstorung und Wiederaneignung von Zeit. 1988. Hrsg. von R. Zoll. Frankfurt am Main: Suhrkamp. 